\title{
Pemanfaatan Hasil Hutan Bukan Kayu (HHBK) pada Ekosistem Mangrove Di Baros, Tirtohargo, Kretek, Bantul
}

\author{
Retno Kusumawiranti \\ Program Studi Ilmu Administrasi Publik, Fakultas Ilmu Sosial dan Ilmu Politik \\ Universitas Widya Mataram \\ E-mail: retno zan@yahoo.co.id
}

\begin{abstract}
This activity is a follow-up of an analysis of the situation surrounding the management of mangrove forests, especially in the Baros region, Tirtohargo, Kretek, Bantul, indicating that the use of non-timber forest products, one of which is mangrove forest tourism, can not be expected. One reason is that eco-tourism of mangrove forests is felt to be unattractive because of the lack of knowledge of the community and the touch or support of various parties. Therefore it is necessary to carry out continuous socialization to the community, through various information disseminations, training, lectures, counseling, promotions so that it will enhance and foster a sense of caring to help maintain and preserve mangrove forests, as well as transactions between surrounding communities and visitors so as to increase community economy. The method used is the lecture method and participatory dialogue. Efforts to develop programs and activities for developing eco-tourism in mangrove forests are opportunities to be developed as objects and attractions. Besides that mangrove land can be used for semi-natural cultivation of commodities that have mangrove habitat such as mangrove crabs or mangrove shells WITHOUT having to change the mangrove ecosystem; while other commodities such as fish and shrimp need a pool of water that must convert part of the mangrove land into a pond.
\end{abstract}

Key words: ecotourism of mangrove forests, non-timber forest

\begin{abstract}
Abstrak
Kegiatan pengabdian ini merupakan tindak lanjut dari analisis situasi yang terjadi di sekitar pengelolaan hutan mangrove khususnya di wilayah Baros, Tirtohargo, Kretek, Bantul, yang menunjukkan bahwa pemanfaatan hasil hutan bukan kayu salah satunya berupa wisata hutan mangrove bisa dikatakan belum sesuai dengan harapan. Salah satu sebabnya adalah ekowisata hutan mangrove dirasakan tidak menarik karena kurangnya pengetahuan masyarakat dan sentuhan atau dukungan dari berbagai pihak. Oleh karenanya perlu dilakukan sosialisasi secara terus menerus kepada masyarakat, melalui berbagai penyebaran informasi, pelatihan, ceramah, penyuluhan, promosi sehingga akan meningkatkan dan menumbuhkan rasa kepedulian untuk ikut menjaga dan melestarikan hutan mangrove, serta terjadinya transaksi antara masyarakat di sekitarnya dengan pengunjung sehingga dapat meningkatkan ekonomi masyarakat. Metode yang digunakan adalah metode ceramah dan dialog partisipatif. Upaya pengembangan program dan kegiatan pengembangan ekowisata hutan mangrove merupakan peluang untuk dikembangkan sebagai objek dan daya tarik. Selain itu lahan mangrove bisa dimanfaatkan untuk budidaya semi alami komoditas yang memiliki habitat mangrove seperti kepiting bakau atau kerang bakau tanpa harus mengubah ekosistem mangrove; sementara komoditas lainnya seperti ikan dan udang memerlukan genangan air yang harus mengubah sebagaian lahan mangrove menjadi tambak.
\end{abstract}

Kata kunci: ekowisata hutan mangrove, hasil hutan bukan kayu, 


\section{PENDAHULUAN}

2.

Hutan merupakan salah satu kekayaan sumberdaya alam Indonesia yang telah memberikan kemanfaatan yang besar bagi berbagai kebutuhan negara maupun sumber kehidupan manusia dan makhluk hidup lainnya. Hutan merupakan sumber penyedia pangan, papan, obat-obatan, sebagai habitat makhluk hidup yang ada di dalamnya, memiliki kegunaan sebagai penyimpan air, penahan banjir, penguat tanah. (Sumintarsih, 2011: 664). Sejak dahulu, hutan menjadi tempat bergantung hidup, hutan menjadi lumbung pangan bagi masyarakat sekitar hutan.

Berkurangnya ekosistem mangrove menjadi perhatian serius negara berkembang, termasuk Indonesia dalam masalah lingkungan dan ekonomi. Berdasarkan manfaat dan fungsi magrove maka mangrove berperanan penting dalam kehidupan manusia. Mangrove merupakan individu/komunitas tumbuhan yang toleran terhadap kadar garam tinggi yang tumbuh pada daerah pesisir pantai tropis-subtropis. Mangrove mengembangkan sistem adaptasi tertentu untuk tumbuh dan berkembang, khususnya pada daerah yang mengandung lumpur dan tergenang.

Data luasan mangrove di Indonesia berdasarkan data RLPS 2007, adalah 9,3 juta ha (3,7 kaw hutan, 5,6 non-kaw). Sedangkan FAO menyebutkan luas mangrove berkis ar antara 2,17 dan 4,25 juta hektar (kawasan hutan). Mangrove di Indonesia memiliki keanekaragaman jenis yang tinggi. Tercatat sekitar 202 jenis vegetasi mangrove terdapat di Indonesia, terdiri dari 89 jenis pohon, 5 jenis palem, 19 jenis liana, 44 jenis epipit dan 1 jenis sikas (Kusmana, 2002).

Keberadaan

hutan

mangrove mempunyai peranan yang sangat penting terutama bila ditinjau dari lingkungannya, baik terhadap lahannya itu sendiri yaitu sebagai penahan erosi pantai (abrasi), bagi kehidupan satwa liar, untuk perkembangbiakan ikan, udang, kepiting dan biota laut maupun dari segi pemanfaatannya oleh manusia untuk dipungut hasilnya (kayu) dan sebagai objek pariwisata serta silfofishery (non kayu). Keberadaan Undang Undang Kehutanan No 41. tahun 1999 bertujuan untuk memperoleh manfaat optimal bagi kesejahteraan seluruh masyarakat secara berkeadilan dengan tetap menjaga kelestariannya.

Ancaman yang timbul bagi sumber daya alam hutan mangrove adalah adanya ketergantungan kehidupan manusia terhadap sumber daya alam tersebut. Hal ini dapat dihindari dengan memanfaatkan sumber daya alam tersebut secara berkelanjutan tanpa merusak ekosistemnya. Sesuai dengan UU No. 24 tahun 1990 tentang kehutanan, dinyatakan bahwa pemanfaatan kawasan hutan dapat dilakukan pada semua kawasan hutan (zona pemanfaatan) kecuali pada hutan cagar alam serta zona inti dan zona rimba pada taman nasional. Sedangkan zona pemanfaatan dapat dimanfaatan sebagai tempat wisata. Ekowisata di hutan mangrove merupakan sesuatu yang unik dan spesifik dengan memperhatikan prinsip-prinsip: konservasi, edukasi, rekreasi, dan ekonomi. Oleh karena 
itu perlu diketahui tingkat pemanfaatan hasil hutan mangrove bukan kayu di Baros, Tirtohargo, Kretek Bantul dengan memperhatikan beberapa prinsip di atas? Oleh karena itu tujuan dari kegiatan pengabdian ini adalah:

1. Untuk memberikan wawasan dan pemahaman kepada masyarakat sekitar ekosistem mangrove tentang pemanfaatan hasil hutan bukan kayu.

2. Untuk memberikan motivasi dan menggugah kesadaran masyarakat sekitar ekosistem mangrove dalam pemanfaatan hasil hutan mangrove dengan memperhatikan prinsipprinsip konservasi, edukasi, rekreasi dan ekonomi.

3. Meningkatkan kesadaran dan kepedulian konservasi dan budaya bagi masyarakat sekitar tentang flora dan fauna yang ada di kawasan hutan mangrove.

Sedangkan yang menjadi manfaat dari kegiatan pengabdian ini adalah sebagai berikut:

1. Diharapkan masyarakat setempat dan sekitarnya dapat memanfaatkan sumber daya alam secara berkelanjutan tetapi tidak merusak ekosistemnya.

2. Diharapkan akan menimbulkan rasa memiliki sehingga mereka ikut menjaga dan melestarikan hutan mangrove.

3. Memberi pengaruh bagi berkembangnya perekonomian masyarakat setempat.

\section{METODE PELAKSANAAN}

Metode yang digunakan adalah metode ceramah dan dialog partisipatif. Sedangkan dalam metode dialog partisipatif, peserta mempunyai kesempatan menanyakan berbagai permasalahan yang mereka hadapi dan temui kepada pembicara secara langsung. Dengan demikian terjadi komunikasi dua arah atau komunikasi timbal balik antara kedua belah pihak.

\section{HASIL DAN PEMBAHASAN}

Kegiatan pengabdian

dilakukan bertempat di Kantor

Kelurahan Tirtohargo, Kretek, Bantul. Kegiatan pengabdian ini berupa penyuluhan dengan mengambil tema tentang pengelolaan hutan mangrove berbasis masyarakat serta pengelolaan paket wisata hutan mangrove yang berbasis pemberdayaan masyarakat. Pada kegiatan pengebdian ini yang menjadi khalayak sasaran yakni pengelola hutan mangrove khususnya Kelompok Pemuda Pemudi Baros/KP2B serta masyarakat sekitar dengan harapan mereka bisa mengurangi kegiatan mereka yang dapat memberikan tekanan terhadap lahan mangrove dan ekosistemnya sehingga nantinya dapat ikut berpartisipasi untuk menjaga fasilitas dan keanekaragaman tumbuhan mangrove yang ada di sekitar kawasan hutan mangrove, serta mereka dapat memanfaatkan kawasan mangrove di sekitarnya untuk menjadi kawasan wisata yang menarik.

Pada kegiatan penyuluhan atau berupa pemaparan materi tersebut mengundang berbagai pertanyaan yang diajukan oleh peserta. Peserta sangat antusias mengikuti pemaparan materi, sebagaimana dalam gambar berikut: 


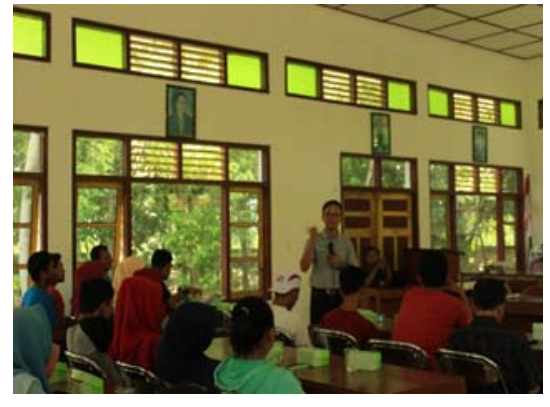

Gambar 1. Kegiatan pemaparan materi.

$\begin{array}{llr} & \text { Pertanyaan yang } & \text { mereka } \\ \text { ajukan di antaranya } & \text { seperti }\end{array}$ berhubung pohon mangrove di Baros Kretek Bantul sudah ada yang mulai berbuah, buah tersebut bisa diubah menjadi produk apa saja apalagi kalau ke depannya buah mangrove melimpah selain ditanam untuk bibit pohon mangrove lagi? Mereka juga mengeluh bahwa sering ada surat permohonan kunjungan sekaligus permintaan untuk mengadakan acara outbound di kawasan mangrove, tetapi mereka selama ini belum sanggup untuk merealisasikan permintaan tersebut, padahal mereka juga menyadari bahwa hal tersebut adalah juga merupakan peluang untuk pengembangan kawasan mangrove menjadi kawasan wisata. Mereka mempertanyakan tentang upaya yang bisa dilakukan untuk mereka bisa merealisasikan permohonan tersebut, termasuk menyiapkan orang-orangnya yang mengerti dan bisa membuat atraksi atau kegiatan outbond?

Berhubung dekade ini manusia lebih cenderung untuk melakukan aktivitas pariwisata di alam. Hutan mangrove adalah merupakan salah satu potensi yang dapat dikembangkan untuk ekowisata sebagai salah satu konsep pemanfaatan sumber daya alam secara lestari. Kegiatan pengabdian selanjutnya adalah berupa penyuluhan sekaligus pemberian pelatihan semacam outbond bagi pengelola hutan mangrove Baros yakni tertuju untuk Kelompok Pemuda Pemudi Baros (KP2B). Ancaman yang timbul bagi sumber daya alam hutan mangrove adalah adanya ketergantungan kehidupan manusia terhadap sumber daya alam tersebut. Hal ini dapat dihindari dengan memanfaatkan sumber daya alam tersebut secara berkelanjutan tanpa merusak ekosistemnya. Pada sesi kegiatan pengabdian ini pemuda pemudi Baros selaku pengelola dan calon pengelola (generasi penerus) sangat antusia mengikutinya. Oleh karena dalam kegiatan ini setelah pemaparan materi dilanjutkan dengan berbagai macam atraksi untuk melatih mereka mengelola kegiatan atraksi wisata yang bisa mereka lakukan sebagai daya tarik tambahan dalam pengelolaan dan pemanfaatan hutan mangrove sebagaimana dalam foto berikut ini:

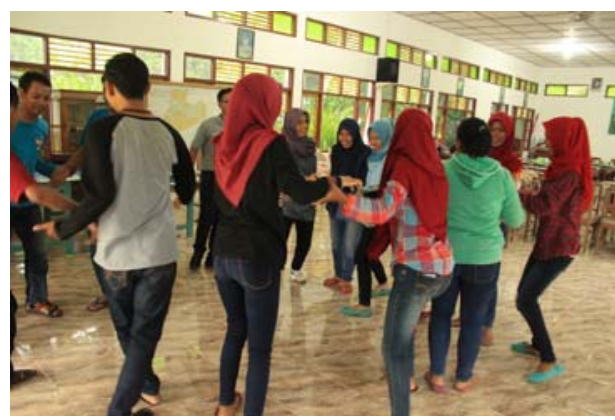

Gambar 2. Kegiatan pelatihan atraksi.

Kegiatan ini dilakukan baik di dalam aula Kantor Kelurahan 
Trihargo, Kretek, Bantul juga dilakukan di halaman luar kantor kelurahan. Peserta dari pemuda pemudi Baros yang tadinya malumalu untuk menunjukkan bakat dan potensi serta kemampuan yang mereka miliki untuk bisa menampilkan berbagai atraksi menarik sebagai salah satu daya tarik wisata tambahan di kawasan hutan Mangrove, misalnya sebagai salah satu bentuk kegiatan outbond. Lama kelamaan mereka sangat menikmati dan antusias bahkan sangat terhibur dengan kegiatan ini.

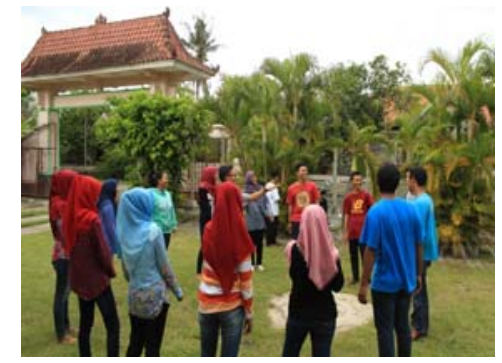

Gambar 3. Kegiatan outbond.

Menurut mereka kegiatan seperti ini adalah kegiatan yang sangat bermanfaat karena selama ini tawaran untuk mengadakan kegiatan outbond dari masyarakat termasuk sekolah-sekolah di Yogyakarta dan skitarnya sering ada tetapi mereka selama ini belum bisa memfasilitasinya.

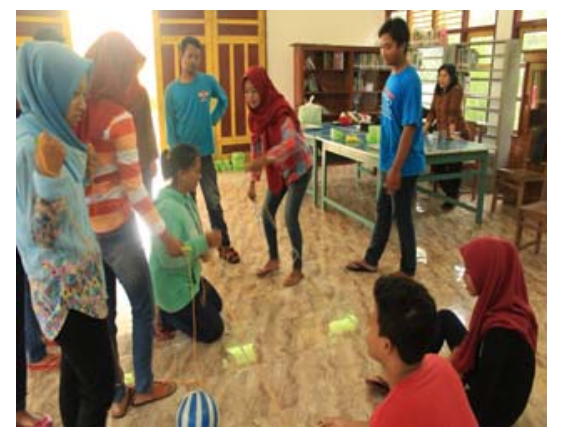

Gambar 4. Kegiatan outbond di dalam ruangan.

\section{PENUTUP}

Melihat antusiasme peserta pengabdian yakni pemuda pemudi Baros dan masyarakat sekitar selaku pengelola dan pemanfaat dari keberadaan hutan mangrove di Baros, Kretek Bantul, tujuan dari kegiatan pengabdian ini bisa tercapai. Anggota Kelompok Pemuda Pemudi Baros (KP2B) dan masyarakat sekitarnya termasuk pihak aparat desa sangat aktif guna terselenggaranya kegiatan pengabdian ini dari mulai koordinasi, penyediaan tempat, membantu penyediaan barang, penyediaan LCD, dan sosialisasi. Berbagai hambatan dan permasalahan yang timbul dan dirasakan selama ini dapat teratasi serta semua peserta mendapatkan kesempatan yang sama untuk mendapatkan materi dan praktek pembuatan atraksi sebagai salah satu paket wisata sebagai daya tarik wisata.

Oleh karena upaya pengembangan pogram dan kegiatan pengembangan ekowisata hutan mangrove merupakan peluang untuk dikembangkan sebagai objek dan daya tarik. Oleh karena itu pemanfaatan Hasil Hutan Bukan Kayu (HHBK) di hutan mangrove adalah ditujukan untuk meningkatkan taraf hidup masyarakat, khususnya masyarakat sekitar hutan mangrove. Pertimbangan ekonomis dan ekologis tidak dapat dipisahkan dalam mengevaluasi berbagai alternatif pengelolaan mangrove.

Harus ada komitment masyarakat dan instansi terkait terhadap pemanfaatan hasil hutan bukan kayu dari hutan mangrove yang tidak 
merusak ekosistem mangrove sehingga bisa meningkatkan kesejahteraan masyarakat sekitar dengan tetap menjaga kelestarian hutan mangrove.

\section{DAFTAR PUSTAKA}

Anwar, J., S.J. Damanik, N. Hisyam, dan A. Whitten. 1984.

Ekologi Ekosistem Sumatra.

Gadjah Mada Univ. Press.

Yogyakarta.

Cecep Kusmana. 2002 . Ekologi Mangrove. Fakultas Kehutanan Institut Pertanian Bogor,

Departemen Kehutanan.1996. Hambatan \& Gangguan Pengelolaan Hutan Mangrove di Indonesia. Lokakarya Strategi Nasional Pengelolaan Hutan Mangrove di Indonesia.

Direktorat Sumber Daya alam dan Teknologi Tepat Guna Pedesaan Direktorat Jenderal Pemberdayaan Masyarakat dan Desa Kementerian Dalam Negeri. 2012. Petunjuk Teknis Pengelolaan Dana Bantuan Langsung Masyarakat (BLM) Pengelolaan Hutan Mangrove Berbasis Pemberdayaan Masyarakat.

Giesen, dkk, - , A Field Guide of Indonesian Mangrove, Bogor : Wetlands InternationalIndonesian Programme.
Hachinoe, dkk, 1998, Manual Persemaian Mangrove - di Bali , Denpasar : PT. Indografika Utama

Kitamura, dkk , 1997 , Handbook of Mangrove in Indonesia - Bali \& Lombok , - : ISME \& JICA

Kusmana, dkk, 2003, Teknik Rehabilitasi Mangrove, Bogor: Fakultas Kehutanan Institut Pertanian Bogor

Noor, Y.R., M. Khazali, dan I.N.N. Suryadiputra,1999, Panduan Pengenalan Mangrove di Indonesia. PKA/WI-IP. Bogor.

Nyoman S. Pendit, 2002, Ilmu Pariwisata Sebuah Pengantar Perdana. Jakarta: Pradnya Paramita.

Spalding, Mark; Kainuma, Mami and Collins, Lorna (2010) World Atlas of Mangroves Earthscan, London, 60 maps showing world-wide mangrove distribution

Sumintarsih, 2011, "Relasi Sosial Ekonomi Petani Hutan Klanggon dalam Menuju Kemandirian" dalam Patrawidya seri Penerbitan Penelitian Sejarah dan Budaya. Yogyakarta: BPSNT, Desember.

Tomlinson, 1986 , The Botany of Mangrove, New York : Cambridge University Press 